\title{
Work overload and risk behaviors in motorcyclists
}

\author{
Sobrecarga de trabalho e comportamentos de risco em motociclistas \\ Sobrecarga de trabajo y comportamientos de riesgo en motociclistas
}

Washington José dos Santos'

ORCID: 0000-0002-2291-8563

Vanessa Maria da Silva Cêlho'

ORCID: 0000-0003-4927-4523

Gustavo Barreto Santos'

ORCID: 0000-0002-9978-8373

Albanita Gomes da Costa de Ceballos' ORCID: 0000-0002-8658-9981

'Universidade Federal de Pernambuco. Recife, Pernambuco, Brazil.

How to cite this article:

Santos WJ, Coêlho VMS, Santos GB, Ceballos AGC. Work overload and risk behaviors in motorcyclists.

Rev Bras Enferm. 2019;72(6):1479-84.

doi: http://dx.doi.org/10.1590/0034-7167-2018-0279

Corresponding Author:

Washington José dos Santos E-mail:washingtonfisio@gmail.com

Submission: 05-09-2018

Approval: 02-19-2019

\begin{abstract}
Objective: to analyze the association between work overload and risk behaviors adopted by motorcyclists. Method: a cross-sectional study of injured motorcycle drivers hospitalized at the Hospital da Restauração Governador Paulo Guerra in the city of Recife, PE, from May to September 2016. A questionnaire was applied containing sociodemographic variables related to work overload and risk behaviors adoption. Odds Ratio (OR) and 95\% Confidence Interval were used to analyze the association between the variables. Results: there was a predominance of males $(97.6 \%)$, mean age 31.44 years $(S D=9.50)$. There was an association of sleep/fatigue at the accident time with difficulties carrying out work tasks $(\mathrm{OR}=3.7)$, feeling tired during work (OR $=4.6)$ and feeling under pressure to carry out work tasks $(O R=3.5)$. Conclusion: work overload was associated with risk behaviors adoption. It is believed that this fact can have an impact on the occurrence and severity of accidents.

Descriptors: Accidents; Traffic; Workload; Risk-Taking; Motorcycles; Risk Groups.
\end{abstract}

\section{RESUMO}

Objetivo: analisar a associação entre sobrecarga de trabalho e comportamento de risco adotado por motociclistas. Método: estudo transversal com trabalhadores acidentados condutores de motocicletas, internados no Hospital da Restauração Governador Paulo Guerra no Recife-PE, no período de maio a setembro de 2016. Aplicou-se um questionário contendo variáveis sociodemográficas relacionadas à sobrecarga de trabalho e adoção de comportamentos de risco. Para análise da associação entre as variáveis, utilizou-se Odds Ratio (OR) e Intervalo de Confiança de 95\%. Resultados: observou-se predomínio do sexo masculino (97,6\%), com média de idade 31,44 anos ( $D P=9,50$ ). Houve associação de sono/fadiga no momento do acidente com dificuldades em realizar tarefas de trabalho $(O R=3,7)$, sentir-se cansado durante o trabalho $(O R=4,6)$ e sentir-se pressionado a realizar tarefas de trabalho $(\mathrm{OR}=3,5)$. Conclusão: a sobrecarga de trabalho associouse à adoção de comportamento de risco. Acredita-se que tal fato pode repercutir na ocorrência e gravidade dos acidentes.

Descritores: Acidentes de Trânsito; Carga de Trabalho; Assunção de Riscos; Motocicletas; Grupos de Risco.

\section{RESUMEN}

Objetivo: analizar la asociación entre sobrecarga de trabajo y comportamiento de riesgo adoptado por los motociclistas. Método: El estudio transversal con trabajadores accidentados conductores de motocicletas, internados en el Hospital da Restauração Governador Paulo Guerra en Recife-PE, en el período de mayo a septiembre de 2016. Se aplicó un cuestionario que contenía variables sociodemográficas relacionadas con la sobrecarga de trabajo y la adopción de comportamientos de riesgo. Para el análisis de la asociación entre las variables, se utilizó el Odds Ratio (OR) y el Intervalo de Confianza del $95 \%$. Resultados: se observó predominio del sexo masculino $(97,6 \%)$, con media de edad 31,44 años ( $D E=9,50)$. Se observó una asociación de sueño/fatiga en el momento del accidente con dificultades en realizar tareas de trabajo $(O R=3,7)$, sentirse cansado durante el trabajo $(O R=4,6)$ y sentirse presionado a realizar tareas de trabajo $(\mathrm{OR}=3,7) \mathrm{OR}=3,5)$. Conclusión: la sobrecarga de trabajo se asoció a la adopción de comportamiento de riesgo. Se cree que tal hecho puede repercutir en la ocurrencia y gravedad de los accidentes.

Descriptores: Accidentes de Tránsito; Carga de Trabajo; Asunción de Riesgos; Motocicletas; Grupos de Riesgo. 


\section{INTRODUCTION}

Deaths and injuries resulting from road traffic accidents (RTC) area serious and growing public health problem, being one of the leading causes of death and disability ${ }^{(1)}$. In Brazil, in 2014, there were 43,780 deaths due to RTC and of these, 12,604 (28.78\%) were motorcyclists ${ }^{(2)}$. In Pernambuco State, there was a 428\% increase in the motorcycle accident mortality coefficient between 1998 and 2009 , from 1.00 to $5.28^{(3)}$.

Between 2008 and 2013, in Brazil, total hospitalizations for accidents of all types of ground transportation grew $72.4 \%{ }^{(4)}$. In the same period, the number of hospital admissions involving motorcyclists injured in traffic increased by $115 \%$. There was also an increase in public spending on care of injured motorcyclists ${ }^{(5)}$. In 2013, of the total of 229 million spent on hospitalizations in the Brazilian Unified Health System (SUS - Sistema Único de Saúde), 112.9 million were with motorcycle accidents.

Motorcycle is an attractive transportation option due to the poor quality of public transportation in most Brazilian urban centers and for facilitating commuting in times of slow traffic. The growth in the number of motorcycles in cities and in the countryside can also be explained by low acquisition and maintenance costs when compared to automobiles. According to the Departamento Nacional de Trânsito (DENATRAN, equivalent to the National Highway Traffic Safety Administration), in December 2016, there were 20,942,633 motorcycles in Brazil(6).

Many of the RTCs can be characterized as occupational accidents (commute or typical), as they occur in the home-work-home commuting or in the motorcycle's own activities, being part of them attributed to the high demand or work overload ${ }^{(7)}$.

Work overload is directly related to emotional exhaustion, activity performance dissatisfaction, quality of life at work on job satisfaction and work, family conflict ${ }^{(8)}$. Incessant fatigue, lack of prospects, frustration, anxiety, depression, fear, job demotivation, and overloading of tasks are detrimental to motorcyclists, negatively influencing their behavior ${ }^{(9)}$. This influence may lead them to adopt risk behavior in traffic ${ }^{(10)}$.

Risk behaviors are linked to motivational and attitude factors ${ }^{(9)}$. These risk behaviors are related to the severity of accidents ${ }^{(11)}$. Disrespect for traffic laws is an example of adopting risk behavior ${ }^{(12)}$, as well as the use of alcohol, speeding, cell phone use, non-use of helmets or other personal protective equipment (PPE) ${ }^{(13-14)}$.

There is little discussion about what makes a motorcycle driver adopt or take risk behavior in traffic. This study is justified by the need to deepen the knowledge about such behaviors to bring evidence that can contribute to measures of prevention of accidents with greater effectiveness.

\section{OBJECTIVE}

To analyze the association between work overload and risk behavior adopted by motorcyclists.

\section{METHOD}

\section{Ethical aspects}

This research was approved by the Research Ethics Committees of the Universidade Federal de Pernambuco and the Hospital da Restauração Governador Paulo Guerra (HR). All individuals who agreed to participate in the study signed the Free and Informed Consent Form.

\section{Design, place of study and period}

It is a cross-sectional study carried out between May and September 2016, at the HR in Recife (PE). The RH was chosen for the research because it is the main trauma unit of Pernambuco State and a sentinel unit of surveillance in ground transportation accidents, and has an average of more than 39 thousand hospitalizations per year.

\section{Population and inclusion and exclusion criteria}

There was no sample calculation. The study population consisted of all workers, motorcycle drivers, hospitalized in the TraumatologyOrthopedics ward of the HR. The following inclusion criteria were established: to be employed, to be the driver of the motorcycle at the accident time and to be aged 18 or over. Exclusion criteria were: patients who had altered levels of consciousness that did not respond to the questionnaire, moderate to severe Glasgow coma scores (12 to 3 ).

\section{Study protocol}

For data collection, a questionnaire prepared by the researchers was used, based on data from the Sistema de Informação de Acidentes de Transporte Terrestre (freely translated as Land Transportation Accident Information System), containing the variables related to sociodemographic characteristics, work overload and risk behavior in traffic. All patients who met the inclusion criteria of the study were invited to participate.

The questionnaires were filled out by the researchers who were approaching at the edge of the bed in which the individuals were hospitalized. The interview time was on average 20 to 30 minutes.

\section{Analysis of results, and statistics}

Typing and statistical analysis were performed by the Statistical Package for the Social Sciences (SPSS), version 20.0. The relationship between the variables related to work overload and risk behavior adoption was analyzed by measuring odds ratios and confidence intervals, assuming an error of 5\% (Odds Ratio (OR) and 95\% Cl).

\section{RESULTS}

144 individuals were searched. There were 12 denials and eight losses (due to the effect of anesthesia after surgery, by transfer or hospital discharge).

Among those surveyed, 121 (97.6\%) were males. The mean age was 31.44 years $(S D=9.50)$, ranging from 18 to 64 years. The main occupation of the studied population was: farmer (12.1\%), merchant (11.3\%) and motoboy/mototaxi driver (9.6\%). The average monthly income reported was less than two minimum wages (75.0\%) and the productive insertion was informal (54.8\%).

Regarding the job demand, $24.6 \%$ of respondents reported having excessive demand in the last three months before the accident. Among those surveyed, 35.2\% said they felt tired at 
work. The lack of professional recognition by the population was reported by $52.8 \%$ of respondents. Concerning the desire for professional improvement, $64.2 \%$ said they see growth prospects in the profession. However, $54.5 \%$ of the total have a desire or expectation of changing jobs (Table 1).

Table 1 - Job demand of the study population, Recife, Pernambuco, Brazil, 2016

\begin{tabular}{ll}
\hline Variables & n $\%$ \\
\hline
\end{tabular}

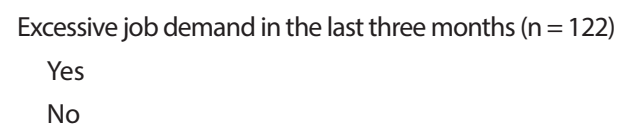

Had difficulty carrying out work tasks due to excessive demand in the last three months $(n=122)$

Yes

$\begin{array}{ll}28 & 22.9\end{array}$

No

$94 \quad 77.1$

Felt tired during work in the last three months $(n=122)$

Yes

No

$43 \quad 35.2$

$\begin{array}{ll}79 & 64.8\end{array}$

Feels under pressure at work $(n=123)$

Yes

No

$29 \quad 23.6$

$94 \quad 76.4$

Feels unhappy with work $(n=123)$

Yes

No

$18 \quad 14.6$

10585.4

Refers to lack of professional recognition by the population $(n=123)$

Yes

$\begin{array}{ll}65 & 52.8\end{array}$

$58 \quad 47.2$

Feels that work invades personal life $(n=123)$ Yes

No

Has little time for himself because of work $(n=123)$

Yes

No

Sees perspective of professional growth $(n=123)$

Yes

No

$\begin{array}{ll}79 & 64.2\end{array}$

$\begin{array}{ll}44 & 35.8\end{array}$

Feels desire to change profession $(n=123)$

Yes

$\begin{array}{ll}67 & 54.5\end{array}$

No

Regarding risk behavior adoption by motorcyclists at the accident time, $20.2 \%$ reported sleep or fatigue, $31.5 \%$ ingested alcoholic beverages, $40.6 \%$ did not have a motorcycle license, $17.1 \%$ did not wear a helmet and $13.0 \%$ reported being in excess of speed when they suffered the accident (Table 2).

There were statistically significant associations between variables related to work overload and sleep/fatigue at the accident

time: difficulties carrying out work tasks due to excessive demand in the last three months $(\mathrm{OR}=3.7 ; \mathrm{Cl}=1.4-9.5)$; feeling tired during work in the last three months $(\mathrm{OR}=4.6 ; \mathrm{Cl}=1.8-11.7)$. Besides, individuals who felt under pressure to carry out work tasks and reported lack of professional recognition on the part of the population presented a 3.5 and 3.6 times greater chance, respectively, of driving the motorcycle with sleep/fatigue (Table 3).

It has also been found that individuals wishing to change their profession have a 3.4-fold chance of driving under the influence of alcohol ( $\mathrm{OR}=3.4 ; \mathrm{Cl}=1.5-7.4)$, and that having little time for himself because of work was associated with not being able to drive a motorcycle $(\mathrm{OR}=0.4 ; \mathrm{Cl}=0.2-0.8)$, as well as not being tired while working with the helmet at the accident day $(\mathrm{OR}=$ 4.0; $\mathrm{Cl}=1.5$ - 10.6) (Table 3).

Table 2 - Risk behavior adoption reported by motorcyclists, Recife, Pernambuco, Brazil,2016

\section{Variables}

n $\%$

Driving drowsy or with fatigue

$\begin{array}{lll}\text { Yes } & 25 & 20.2 \\ \text { No } & 99 & 79.8\end{array}$

Driving after drinking alcoholic beverage

Yes

$39 \quad 31.5$

No

Driving after controlled medication ingestion $(n=123)$

Yes

$6 \quad 4.9$

No

Driving after illicit drugs use

Yes

No

Driving using the mobile

$\begin{array}{ccc}\text { Yes } & 2 & 1.6 \\ \text { No } & 122 & 98.4\end{array}$

Does not have a motorcycle license $(n=123)$

Yes

$50 \quad 40.6$

No

Absence of helmet at the accident time $(n=123)$

Yes

$21 \quad 17.1$

No

Does not use other PPE at the accident time

Yes

No

Disrespect for signs at the accident time $(n=121)$

$$
\begin{array}{ccc}
\text { Yes } & 8 & 6.6 \\
\text { No } & 113 & 93.4
\end{array}
$$

Excess speed at the accident time $(n=123)$ 


\begin{tabular}{|c|c|c|c|c|}
\hline Variables & $\begin{array}{c}\text { Driving } \\
\text { drowsy or } \\
\text { with fatigue } \\
\text { OR }(95 \% \mathrm{CI})\end{array}$ & $\begin{array}{l}\text { Driving after } \\
\text { drinking } \\
\text { alcoholic } \\
\text { beverage } \\
\text { OR }(95 \% \mathrm{Cl})\end{array}$ & $\begin{array}{c}\text { Having } \\
\text { motorcycle } \\
\text { license } \\
\text { OR }(95 \% \mathrm{CI})\end{array}$ & $\begin{array}{l}\text { Absence of } \\
\text { helmet at the } \\
\text { accident time } \\
\text { OR }(95 \% \mathrm{CI})\end{array}$ \\
\hline Excessive job demand in the last three months & $2.7(1.0-6.6)$ & $1.4(0.6-3.3)$ & $0.9(0.4-2.0)$ & $1.0(0.3-3.0)$ \\
\hline Had difficulty carrying out work tasks due to excessive demand in the last three months & $3.7(1.4-9.5)$ & $1.6(0.7-3.9)$ & $1.2(0.5-2.9)$ & $2.6(1.0-7.2)$ \\
\hline Felt tired during work in the last 3 months & $4.6(1.8-11.7)$ & $1.1(0.5-2.5)$ & $1.6(0.7-3.3)$ & $4.0(1.5-10.6)$ \\
\hline Sente-se pressionado no trabalho & $3.5(1.4-8.9)$ & $0.8(0.3-2.0)$ & $0.6(0.3-1.6)$ & $1.1(0.4-3.2)$ \\
\hline Felt unhappy with work & $0.2(0.0-1.6)$ & $0.8(0.3-2.6)$ & $0.5(0.2-1.6)$ & $1.5(0.4-5.0)$ \\
\hline Lack of professional recognition by the population & $3.6(1.3-9.7)$ & $1.0(0.5-2.1)$ & $0.8(0.4-1.6)$ & $1.5(0.6-4.0)$ \\
\hline Feels that work invades personal life & $2.1(0.8-5.6)$ & $1.0(0.4-2.5)$ & $0.7(0.3-1.8)$ & $0.3(0.1-1.6)$ \\
\hline Has little time for himself because of work & $1.5(0.6-3.6)$ & $0.8(0.4-1.7)$ & $0.4(0.2-0.8)$ & $0.4(0.2-1.2)$ \\
\hline Sees perspective of professional growth & $0.6(0.2-1.7)$ & $0.9(0.4-2.0)$ & $0.7(0.3-1.4)$ & $1.1(0.4-2.9)$ \\
\hline Desire to change profession & $0.5(0.2-1.2)$ & $0.3(0.1-0.7)$ & $0.5(0.2-1.0)$ & $0.7(0.3-1.9)$ \\
\hline
\end{tabular}

\section{DISCUSSION}

The sociodemographic profile found in this research is similar to other literary findings, in which the majority of the injured are male, young, low income, economically active age $\mathrm{e}^{(5,7,12,14)}$.

The results of the study found associations of work overload with the "driving drowsy or with fatigue at the accident day" outcome. Work overload seems to be involved with the attention of motorcyclists in traffic. The attention distributed in several factors and the low concentrated attention may be related to the incidence and recurrence of traffic accidents ${ }^{(15)}$ and a greater history of collisions and traffic fines ${ }^{(16)}$.

Regarding risk behaviors in traffic, a significant portion reported having ingested alcohol before the accident. This number may be underestimated due to the fear of being held accountable for the accident. Besides being a crime, according to the Brazilian Traffic Code (Law 9,503/97) ${ }^{(17)}$, alcohol beverages intake changes the time of the reflexes, causes a sensation of euphoria that induces the driver to abuse the speed, causing the loss of the control of the motorcycle ${ }^{(18)}$.

The proportion of accident victims who did not have the Brazilian Driver's License (CNH) to drive a motorcycle was high. The said document is mandatory for driving the vehicle, according to Brazilian traffic legislation, and not owning it can put both the life of the motorcyclist at risk and the other users of the roads. The accident victims who reported not having $\mathrm{CNH}$ had a lower mean age (29.04 SD $= \pm 9.23$ ) than those allowed (33.15 SD $= \pm$ 9.43). Risk behaviors are particularly adopted by younger drivers as they tend to overlook the possibility of an accident, presenting a high level of risk acceptance in traffic situations ${ }^{(19)}$.

More than $15 \%$ of the motorcyclists did not wear the helmet at the accident time, although the Brazilian Traffic Code prohibits piloting without this equipment. In addition, most motorcyclists also reported not using other PPE, being vulnerable to injury in larger bodily extensions and more severely. PPE is essential for reducing the risk of injury in the event of an accident, and its use reduces the incidence of traumatic brain injury and death ${ }^{(20)}$.

There were reports of disrespect for traffic signs, and motorcycle driving in excess of speed. Such situations are due to the stress and anxiety of daily life, causing drivers, in the search for their space, to adopt a more aggressive behavior in traffic. Moreover, it is believed that the lack of inspection of public agents in some ways and impunity are aspects that contribute to the law being disobeyed.

Mobile phone use when riding a motorcycle represents safety risk $^{(21)}$. A study on the frequency of motorcycle use by motorcyclists observed a total of 4,244 motorcyclists, with a general use rate of $0.64 \%$. It is considered that this factor should be monitored, given the growing popularity of motorcycles and mobile phones ${ }^{(22)}$. Research on the use of social networks in the cell phone, when driving motorcycle, evidenced a clear association with a greater propensity to accidents / falls to those who talked with girlfriend or boyfriend or spouse ${ }^{(21)}$.

Regarding the association between work characteristics and traffic risk behaviors adoption, it was observed that motorcyclists who reported a desire to change their profession, ingested more alcoholic beverage. Job dissatisfaction, unfulfilled expectations and frustrated aspirations are considered some of the reasons for alcohol consumption among workers ${ }^{(23)}$.

Another aspect observed was that people who reported being tired during work used fewer helmets than non-fatigued ones, thus becoming more susceptible to more serious accidents due to greater exposure of the head and face. Work overload can cause physical and mental fatigue, making it difficult for self-care actions that are essential for the health promotion of individuals ${ }^{(24)}$.

Drowsy driving is an important factor in traffic accidents caused by human error ${ }^{(25)}$, causing thousands of deaths and injuries each year, as sleep and/or fatigue, reduces the alertness of drivers ${ }^{(26)}$. A study on the association between insufficient sleep hours and the different types of risk behaviors among motorcyclists revealed that motorcyclists with sleep insufficiency are more likely to drive more risky, especially for speed, equipment control and related risk behaviors to errors ${ }^{(27)}$.

Motorcyclists must continually acquire and process a number of information through their eyes, ears and other sensory organs in order to prevent accidents. This information includes other vehicles and pedestrians, guidance provided by road signs and traffic signs, and various situations and changes in the road environment ${ }^{(28)}$. 


\section{Study limitations}

This research may present limitations related to some omission of information, especially on the most sensitive issues, for fear of judgment or punishment, such as, for example, issues regarding illegal drugs use at the accident day or driving vehicle talking on the cell phone.

\section{Contributions to the fields of Nursing, Health or Public Policy}

Lack of research on the subject justifies the relevance of work in order to contribute to the surveillance and prevention of these accidents, in addition to the growing importance of motorcycle accidents in the country.

\section{CONCLUSION}

This study concluded that work overload is associated with traffic risk behaviors adoption in the study population. These findings will contribute to reveal the characteristics of this problem, subsidizing the implementation of intersectoral public policies focused on preventive measures adoption for this specific group of injured people.

\section{REFERENCES}

1. Organização Mundial da Saúde (OMS). Organização Pan-Americana da Saúde (OPAS). Capacetes: manual de segurança no trânsito para gestores e profissionais de saúde [Internet]. Brasília: OPAS; 2007 [cited 2017 May 9]. Available from: https://apps.who.int/iris/bitstream/ handle/10665/43261/9241562994_por.pdf;jsessionid=E8FAAD51D8C696122AF3A6B39588B831?sequence=4

2. Ministério da Saúde (BR). Departamento de Informática do Sistema Único de Saúde (DATASUS). Óbitos por causa externa no Brasil, 2014[Internet]. Brasília; 2017 [cited 2017 May 9]. Available from: http://tabnet.datasus.gov.br/cgi/tabcgi.exe?sim/cnv/ext10br.def

3. Lima MLC, Cesse EAP, Abath MB, Oliveira Jr FJM. Tendência de mortalidade por acidentes de motocicleta no Estado de Pernambuco, no período de 1998 a 2009. Epidemiol Serv Saúde. 2013;22(3):395-402. doi: http://dx.doi.org/10.5123/S1679-49742013000300004

4. Ministério da Saúde (BR). Governo vai lançar plano nacional de prevenção de acidentes de trânsito[Internet]. Brasília; 2019 [cited 2015 Aug 3]. Available from: http://www.brasil.gov.br/saude/2015/07/governo-vai-lancar-plano-nacional-de-prevencao-de-acidentes-de-transito

5. Soriano EP, Carvalho MVD, Montenegro JB, Campello RIC, Almeida AC, Lins Filho JD, et al. Violência no trânsito: uma década de vidas perdidas em acidentes motociclísticos no Brasil [Internet]. Derecho Cambio Soc. 2013[cited 2015 Aug 3];31:1-12. Available from: https:// dialnet.unirioja.es/servlet/articulo?codigo $=5490757$

6. Ministério da Infraestrutura (BR). Departamento Nacional de Trânsito (DENATRAN). Frota de veículos - 2016. [Internet]. Brasília; 2016 [cited 2017 May 17]. Available from: http://www.denatran.gov.br/index.php/estatistica/261-frota-2016

7. Silva DW, Andrade SM, Soares DFPP, Mathias TAF, Matsuo T, Souza RKT. Factors associated with road accidents among Brazilian motorcycle couriers. Scientific World J. 2012;2012:605480. doi: 10.1100/2012/605480

8. Pérez JP. Effect of burnout and work overload on the quality of work life. Estud Gerenc. 2013;29(129):445-55. doi: 10.1016/j. estger.2013.11.010

9. Jafarpour S, Rahimi-Movaghar V. Determinants of risky driving behavior: a narrative review [Internet]. Med J Islam Repub Iran. 2014;28:142 [cited 2017 May 17]. Available from: https://www.ncbi.nlm.nih.gov/pmc/articles/PMC4322337/

10. Schlichting C, Cavalheiro EG, Felizari CT. A avaliação da qualidade de vida do profissional motociclista através do método WHOQOL-BREF [Internet]. Rev Eletrôn Fac Evang Paraná. 2012[cited 2015 Aug 3];2(2):22-42. Available from: http://www.fepar.edu.br/revistaeletronica/index. $\mathrm{php} / \mathrm{revfepar/article/view/45/57}$

11. Tao $D$, Zhang $R, Q u X$. The role of personality traits and driving experience in self-reported risky driving behaviors and accident risk among Chinese drivers. Accid Anal Prev. 2017 feb;99(Part A):228-35. doi: 10.1016/j.aap.2016.12.009

12. Hongsranagon $P$, Khompratya T, Hongpukdee S, Havanond P, Deelertyuenyong N. Traffic risk behavior and perceptions of Thai motorcyclists: a case study. IATSS Research. 2011;35(1):30-3. doi: 10.1016/j.iatssr.2011.03.001

13. Stephens AN, Brown J, de Rome L, Baldock MRJ, Fernandes R, Fitzharris M. The relationship between Motorcycle Rider Behaviour Questionnaire scores and crashes for riders in Australia. Accid Anal Prev. 2017;102:202-12. doi: 10.1016/j.aap.2017.03.007

14. Heydari ST, Vossoughi M, Akbarzadeh A, Lankarani KB, Sarikhani Y, Javanmardi K, et al. Prevalence and risk factors of alcohol and substance abuse among motorcycle drivers in Fars province, Iran. Chin J Traumatol. 2016;19(2):79-84. doi: 10.1016/j.cjtee.2015.12.006

15. Sprenger D, Costa E, Borges A, Pessoto F, Montiel JM, Bartholomeu D, et al. Avaliação da atenção em uma amostra de motociclistas [Internet]. Salud Soc. 2015;6(1):10-20 [cited 2017 maio 17]. Available from: http://www.redalyc.org/articulo.oa?id=439742477001

16. Nucciarone MI, Poó FM, Tosi JD, Montes SA. La inatención como factor de riesgo en conductores de moto. Temas Psicol. 2012; 20(2):479-89. doi: 10.9788/TP2012.2-15

17. Palácio do Planalto (BR). Lei no 9.503, de 23 de setembro de 1997. Institui o Código Brasileiro de Trânsito. [Internet]. Brasília; 1997 [cited 2017 May 25]. Available from: http://www.planalto.gov.br/ccivil_03/leis/L9503.htm

18. Fell JC, Fisher DA, Voas RB, Blackman KI, Tippetts AS. The impact of underage drinking laws on alcohol-related fatal crashes of young drivers. Alcohol Clin Exp Res. 2009;33(7):1208-19. doi: 10.1111/j.1530-0277.2009.00945.x 
19. Lin MR, Kraus JF. A review of risk factors and patterns of motorcycle injuries. Accid Anal Prev. 2009;41(4):710-22. doi: 10.1016/j. aap.2009.03.010

20. Hassan A, Jokar TO, Rhee P, Ibraheem K, Kulvatunyou N. Anderson KT, et al. More helmets fewer deaths: motorcycle helmet legislation impacts traumatic brain injury-related Mortality in young adults. Am Surg [Internet]. 2017[cited 2017 May 25];83(6):541-6. Available from: https://www.ncbi.nlm.nih.gov/pubmed/28637553

21. De Gruyter C, Truong LT, Nguyen HTT. Who's calling? Social networks and mobile phone use among motorcyclists. Accid Anal Prev. 2017;103:143-7. doi: 10.1016/j.aap.2017.04.010

22. Pérez-Núñez R, Hidalgo-Solórzano E, Vera-López JD, Lunnen JC, Chandran A, Hijar M, et al. The prevalence of mobile phone use among motorcyclists in three Mexican cities. Traffic Inj Prev. 2014;15(2):148-50. doi: 10.1080/15389588.2013.802776

23. Kalimo R, Elbatawi MA, Cooper CL, organizadores. Los fatores psicosociales en el trabajo y su relacion con la salud [Internet]. Ginebra: Organización Mundial de la Salud; 1988 [cited 2015 Aug 3]. Available from: https://apps.who.int/iris/ handle/10665/37881

24. Moreira AKF, Santos ZMSA, Caetano JA. Aplicação do modelo de crenças em saúde na adesão do trabalhador hipertenso ao tratamento. Physis. 2009;19(4):989-1006. doi: 10.1590/S0103-73312009000400005

25. Komada Y, Asaoka S, Abe T, Inoue Y. Short sleep duration, sleep disorders, and traffic accidents. IATSS Research. 2013;37(1):1-7. doi: 10.1016/j.iatssr.2013.06.001

26. Higgins JS, Michael J, Austin R, Åkerstedt T, Van Dongen HPA, Watson N, et al. Asleep at the wheel - the road to addressing drowsy driving. SLEEP. 2017;40(2):zsx001. doi: 10.1093/sleep/zsx001

27. Chen YC, Chen PL. Insufficient sleep hours associated with varied types of risky riding behaviors among motorcyclist. Eur J Public Health. 2016;26(Suppl 1):ckw175.006. doi: 10.1093/eurpub/ckw175.006

28. Ohtsuka R, Wang J, Chihara T, Yamanaka K, Morishima K, Daimoto H. Estimation of mental workload during motorcycle operation. Procedia Manuf. 2015;3:5313-18. doi: 10.1016/j.promfg.2015.07.630 